\title{
Erratum to: Gender differences in health-related quality-of-life are partly explained by sociodemographic and socioeconomic variation between adult men and women in the US: evidence from four US nationally representative data sets
}

Dasha Cherepanov $\cdot$ Mari Palta $\cdot$ Dennis G. Fryback • Stephanie A. Robert

Published online: 13 August 2010

(C) Springer Science+Business Media B.V. 2010

Erratum to: Qual Life Res

DOI 10.1007/s11136-010-9673-x

Figure 1 in the Original publication contains the following error.
The order of the labels, "* + Education" and "* + Marital status", on the horizontal axes was switched.

The online version of the original article can be found under doi:10.1007/s11136-010-9673-x.

D. Cherepanov ( $\square)$

Department of Health Services, University of California,

Los Angeles School of Public Health, P.O. Box 90095-1772,

Los Angeles, CA, USA

e-mail: dcherepanov@ucla.edu

D. Cherepanov

The RAND Corporation, 1776 Main Street. M5S,

Santa Monica, CA 90407-2138, USA

M. Palta · D. G. Fryback - S. A. Robert

Department of Population Health Sciences,

University of Wisconsin School of Medicine and Public Health,

707 WARF, Building, 610 North Walnut Street,

Madison, WI 53726, USA 